\title{
Penerapan Diversifikasi Produk Perikanan di Desa Darunu Kabupaten Minahasa Utara
}

\author{
Lena Damongilala dan Netty Salindeho \\ Fakultas Perikanan dan Ilmu Kelautan, Universitas Sam Ratulangi. \\ Jl. Kampus Unsrat Bahu, Manado 95115, Sulawesi Utara, Indonesia. \\ *Penulis Korespondensi: lenajeane@unsrat.ac.id \\ (Diterima 30-08-2019; Direvisi 17-10-2019; Dipublikasi 10-10-2020)
}

\begin{abstract}
Community Partnership Program (PKM) is an activity to empower community members as a form of partnership among academia, the community and the government. The program aims to improve the skills, production and welfare of the community. The program's target partners are located in the village of Darunu, Wori District, North Minahasa Regency. Geographically located on the coast with potential for marine fisheries that have the potential to be developed. The village is categorized as a fishing community, where around $30 \%$ are classified as poor families and have a small business as fish sellers of fish processors. The specific target of activities is to produce superior diversified products in terms of taste, sanitation and hygiene, as well as to provide business continuity for diversification of fish meatball products, dragon legs, and fish nuggets. The issue that has to be solved is that how to utilize fishery products during abundant harvests. The methods applied in this program are 1) Training of how to produce fish products using good manufacturing practices; 2) Mentoring and evaluation on the way the partners handling fish product.

Keyword: diversification, fish processing, partnership
\end{abstract}

\begin{abstract}
ABSTRAK
Program Kemitraan Masyarakat (PKM) merupakan kegiatan pemberdayaan anggota masyarakat sebagai bentuk kemitraan dengan kesepakatan antara tim, masyarakat dan pemerintah. Program ini bertujuan untuk meningkatkan keterampilan, produksi dan kesejahteraan masyarakat. Mitra sasaran program ini berlokasi di desa Darunu Kecamatan Wori, Kabupaten Minahasa Utara. Secara geografis terletak di pesisir pantai dengan potensi perikanan laut yang potensial untuk dikembangkan. Desa ini dikategorikan sebagai masyarakat nelayan, dimana sekitar 30\% tergolong keluarga miskin dan mempunyai kelompok usaha kecil penjual dan pengolah ikan yang merupakan salah satu produk olahan yang digemari oleh masyarakat sekitar pemasaran sebagian tersebar pada pasaran lokal. Target khusus kegiatan yaitu menghasilkan produk diversifikasi yang unggul dari segi rasa, sanitasi dan higienis, serta memberikan kelangsungan usaha diversifikasi produk Bakso ikan, Kaki Naga, dan Nugget ikan. Permasalahan mitra yaitu pemanfaatan hasil perikanan yang belum tertangani terutama saat panen melimpah. Metode pelaksanaan yang diterapkan pada program ini yaitu 1) Penyuluhan cara pemanfaatan produksi perikanan yaitu aspek produksi dan manajemen, 2) Metode pendekatan yang ditawarkan untuk mengatasi persoalan mitra yakni pelatihan, pendampingan dan evaluasi; 3) Prosedur kerja untuk mendukung kedua aspek permasalahan, berturut-turut yaitu survey, penyuluhan, pelatihan, evaluasi, pelaporan.
\end{abstract}

Kata kunci: diversifikasi, pengolah ikan, kemitraan.

\section{PENDAHULUAN}

Program Kemitraan Masyarakat merupakan kegiatan pemberdayaan anggota masyarakat sebagai bentuk kemitraan dengan kesepakatan antara tim pelaksana, masyarakat dan pemerintah. Desa Darunu salah satu tujuan program dimaksud. Masyarakat desa Darunu sebagian besar (70\%) berprofesi sebagai nelayan. Letak geografis desa ini berada di wilayah Kecamatan Wori, Kabupaten Minahasa Utara dengan jumlah penduduk 635 jiwa (Data, 2017). Kelompok keluarga miskin berjumlah $23 \mathrm{KK}$ dan keluarga penerima raskin $82 \mathrm{KK}$. Fasilitas pendidikan terdapat $1 \mathrm{TK}, 1$ PAUD, 1 SD dan 1 SLTP. Umumnya masyarakat tinggal di pesisir pantai, dan memiliki potensi perikanan laut yang potensial untuk dikembangkan. Bahan baku berupa ikan dan hasil laut lainnya dalam menghidupi keluarga sehari-hari didapat dari aktivitas melaut, sehingga dari segi kualitas memiliki kelebihan yakni bahan bakunya masih bermutu baik karena hasil perikanan baru ditangkap.

Pengetahuan masyarakat khususnya para kaum wanita/ibu tentang diversifikasi atau penganekaragaman pangan bersumber ikan dan hasil perikanan lainnya masih sangat terbatas, sehingga perlu ditingkatkan melalui alih teknologi. Salah satu bentuk diversifikasi pangan bersumber 
ikan ialah mengolah ikan menjadi produk bakso, kaki naga dan nugget ikan. Produk diversifikasi ini diharapkan dapat memenuhi kebutuhan masyarakat akan nutrisi dari daging ikan terutama protein, sekaligus juga meningkatkan kesehatan masyarakat, lebih khusus para anak-anak, wanita/ibu serta masyarakat di desa Darunu. Hal ini menjadi alasan pemilihan penerapan produk diversifikasi, karena ikan tersedia cukup melimpah.

Peranan mitra dalam meningkatkan dan menghasilkan keluarga yang sehat dan berkualitas merupakan tujuan dari setiap keluarga, termasuk masyarakat desa Darunu. Untuk itu kebutuhan gizi lebih khusus protein dari masyarakat perlu ditingkatkan, agar diperoleh warga masyarakat yang sehat, baik jasmani maupun rohaninya. Guna membantu masyarakat dalam meningkatkan gizinya, dibutuhkan pengetahuan tentang manfaat dan nilai gizi ikan, dalam bentuk pelatihan pembuatan nugget, kaki naga dan bakso ikan. Sasaran program ini diarahkan pada kelompok PKK desa, meliputi wanita/ibu rumah tangga nelayan dengan memberikan pengetahuan dan wawasan yang lebih luas tentang nilai gizi ikan serta diversifikasi produk dalam bentuk Nugget ikan, kaki naga dan bakso ikan. Diharapkan para ibu akan menyajikan produk yang lebih bervariasi dan menarik untuk dikonsumsi, sehingga pada akhirnya meningkatkan kesehatan masyarakat yang mengkonsumsinya. Adanya program kemitraan bertujuan mentransfer ilmu pengetahuan dan teknologi khususnya di bidang perikanan. Ikan yang tergolong kurang enak supaya dapat dimakan dalam jumlah yang banyak perlu diadakan diversifikasi berbagai produk olahan. Diversifikasi pangan adalah sebuah program yang mendorong masyarakat untuk memvariasikan makanan pokok yang dikonsumsinya sehingga tidak terfokus pada satu jenis makanan. Diversifikasi pangan berperan dalam pemenuhan kebutuhan gizi masyarakat sehingga nutrisi yang diterima tubuh dapat bervariasi dan seimbang (Permentan N0. 15 tahun 2013). Sasaran diversifikasi pengolahan ikan ditujukan kepada para ibu supaya dapat menciptakan pola makan yang B2SA (Beragam, Bergizi Seimbang dan Aman) dan P2KP (Peningkatan Penganekaragaman Konsumsi Pangan) terutama bagi ibu hamil dan anak-anak. Pembentukan kelompok masing-masing terdiri atas 4 orang. Kedua kelompok sebagai sasaran pemberdayaan dinyatakan sebagai kelompok Desa Darunu A dan kelompok Desa Darunu B. Berdasarkan permasalahan yang ada pada kedua kelompok di desa Darunu, maka diperlukan penyuluhan, pelatihan, pendampingan dan evaluasi dalam penganekaragaman bentuk olahan ikan berupa: pembuatan kaki naga, bakso ikan, nugget ikan dan selai rumput laut, yang sangat dibutuhkan oleh masyarakat dalam rangka mewujudkan program pemerintah dalam hal penyediaan pola makanan keluarga yang berbasis B2SA dan P2KP.

\section{METODE KEGIATAN}

Metode yang dilakukan pada kegiatan program kemitraan masyarakat yaitu (1). Penyuluhan, penyampaian materi kepada kelompok PKK dan pengolah yang ada di desa Darunu Kecamatan Wori Kabupaten Minahasa Utara, menyangkut: cara penanganan ikan yang baru ditangkap secara baik, tepat dan saniter; pentingnya mengolah ikan melalui diversifikasi produk olahan; peranan protein ikan bagi ibu hamil dan anak; penyediaan pola makan yang B2SA. Percepatan penganekaragaman konsumsi pangan agar tidak terfokus pada satu jenis pangan. Cara pembuatan kaki naga dan nugget ikan. Pelatihan, dilakukan kepada ibu-ibu PKK dan pengolah di Desa Darunu. Pelatihan diadakan setelah para ibu mengikuti penyuluhan, sebagai produk diversifikasi olahan ikan. Tujuan dari pelatihan ini agar para ibu mengetahui manfaat dan pentingnya penyediaan bahan makanan yang beranekaragam. Daging ikan dapat dikonsumsi dalam jumlah yang besar sesuai dengan jumlah yang dianjurkan sehingga dihasilkan anak yang cerdas, sehat dan kuat, serta dapat menambah penghasilan bagi ibu-ibu untuk menopang perekonomian rumah tangga. Pendampingan, dilakukan kepada kedua mitra meliputi penyuluhan dan pelatihan pembuatan olahan diversifikasi: kaki naga ikan, nugget ikan dan bakso ikan. Evaluasi, dilaksanakan setelah semua kegiatan penyuluhan, pelatihan dan pendampingan telah selesai melalui penilaian tingkat kesukaan produk dengan cara mencicip.

\section{HASIL DAN PEMBAHASAN}

Pengetahuan tentang penanganan ikan segar yang baik, cepat, tepat serta saniter sangat dibutuhkan para pelaku usaha di bidang perikanan. Hal ini disadari karena daging ikan mempunyai sifat mudah busuk, padahal ikan merupakan sumber protein hewani yang murah, mudah didapat, 
terutama memiliki jaringan daging yang lunak dibandingkan dengan sumber protein yang lain diantaranya daging sapi, ayam, kambing dan lainnya. Jika ikan sudah busuk atau mulai mengalami kemunduran mutu, berarti kandungan protein akan menurun mutunya dan lama-kelamaan akan menjadi rusak, sehingga peranan protein yang diharapkan tidak akan tercapai. Penanganan ikan segar harus dalam kondisi dingin sekitar $0^{\circ} \mathrm{C}$, agar supaya proses pembusukan dapat dihambat. Ikan yang dibeli di pasar biasanya sudah tidak dalam kondisi dingin, sehingga ikan yang telah dibeli di pasar harus segera ditangani yaitu disiangi dengan cara mengeluarkan sisik, sirip, insang dan isi perut. Dicuci bersih dengan air yang mengalir kemudian ditiriskan lalu ditambahkan jeruk untuk menghilangkan rasa amis pada ikan dan garam sebagai penambah rasa. Jika hal ini dilakukan dengan tepat, cepat dan saniter, maka apabila ikan dimasak akan diperoleh ikan yang lezat, dan nikmat. Pengetahuan masyarakat Desa Darunu tentang sumber protein yang bergizi dan sehat secara umum, termasuk diversifikasi pangan bersumber dari ikan masih rendah. Salah satu penyebabnya ialah masyarakat kurang memiliki akses dan informasi untuk memperoleh pengetahuan tersebut. Untuk meningkatkan pengetahuan tentang pangan bersumber ikan, perlu diberi pelatihan tentang berbagai produk diversifikasi, antara lain pembuatan kaki naga, nugget, dan bakso berbahan dasar daging ikan. Hal ini dimaksudkan, agar para wanita/ibu nelayan mendapatkan pengetahuan serta mampu membuat kaki naga, nugget dan bakso ikan sebagai sumber protein dalam menu sehari-hari. Dengan memberikan pengetahuan dan wawasan yang lebih luas tentang nilai gizi ikan serta diversifikasi produk dalam bentuk kaki naga dan bakso ikan, diharapkan para ibu akan menyajikan produk yang lebih bervariasi dan menarik untuk dikonsumsi, sehingga akhirnya meningkatkan kesehatan masyarakat yang mengkonsumsinya. Ikan yang demikian dijamin mutu proteinnya masih bagus. Peranan protein bagi ibu hamil dan anak-anak sangat dibutuhkan untuk pertumbuhan, terutama pertumbuhan janin bagi ibu hamil dan pertumbuhan dan perkembangan terutama otak anak. Jika kebutuhan protein terpenuhi untuk ibu hamil dan anak-anak, maka akan dihasilkan generasi baru yang sehat, kuat dan cerdas. Suatu negara akan kuat dan makmur jika di dalamnya terdapat generasi muda yang sehat, kuat dan cerdas. Kebutuhan protein untuk ibu hamil meningkat sampai $68 \%$ dibandingkan pada waktu sebelum hamil. Dianjurkan mengkonsumsi protein sebanyak $12 \mathrm{~g} / \mathrm{hari}$ selama hamil atau minimal 60 gram ikan/hari. Kebutuhan protein untuk anak umur 0,5-2 tahun adalah $20 \mathrm{gram} / \mathrm{hari}$ atau $100 \mathrm{gram} \mathrm{ikan} / \mathrm{hari}$ dan kebutuhan protein untuk anak 2-5 tahun adalah 35 gram/hari atau 175 gram ikan/hari (kebutuhan gizi bayi dan balita). Ikan yang enak mempunyai harga yang mahal dan diolah apa saja tetap enak. Ikan tersebut hanya dapat dijangkau oleh kalangan masyarakat ekonomi menengah ke atas (Damongilala, 2017; Endang, 2013). Gambar 1 berikut memperlihatkan kegiatan pemberian materi berkaitan dengan pemanfaatan hasil tangkapan dan makan ikan pada kelompok wanita/ibu PKK di desa Darunu kecamatan Wori, Kabupaten Minahasa Utara.

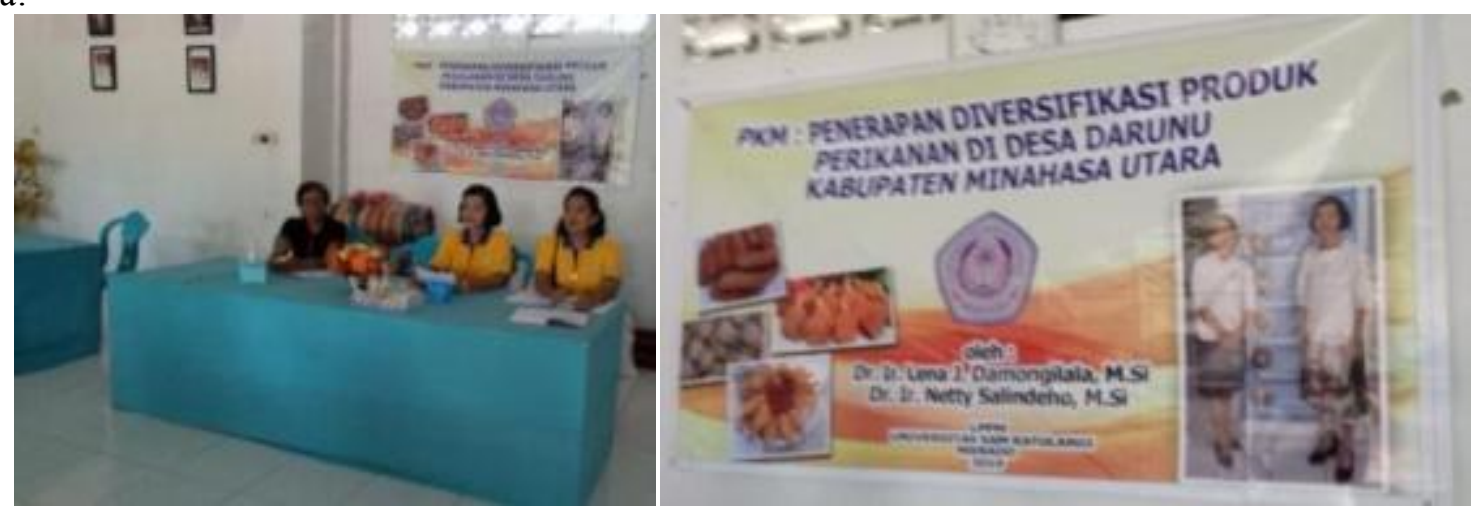

Gambar 1. Penyuluhan tentang pemanfaatan hasil Tangkapan ikan.

Keberadaan ikan yang tersedia di pasaran dapat dikategorikan atas kelompok pertama adalah ikan yang dikenal enak dagingnya, yaitu ikan dengan ketersediaan dalam jumlah terbatas dengan harga mahal. kelompok ikan ini hanya dibeli oleh orang-orang kelas menengah ke atas. Kelompok kedua adalah ikan yang tersedia banyak di pasaran dengan harga murah, dan rasanya kurang enak dibandingkan dengan kelompok ikan pertama. Penganekaragaman olahan ikan terhadap kelompok ikan pertama kurang tepat dan tidak dianjurkan. Hal ini disebabkan karena kelompok ini tersedia terbatas dan harga mahal. Disamping itu akan tetap disantap karena rasanya dagingnya yang enak. 
Jenis ikan kelompok kedua selalu tersedia cukup banyak dengan harga yang terjangkau, sehingga setiap hari masyarakat mengkonsumsinya. Hal ini menimbulkan rasa bosan walaupun diolah dengan bermacam-macam menu, seperti: goreng saus, woku, goreng, dan dibakar. Untuk mencegah kebosanan tersebut, maka perlu dilakukan variasi bentuk olahan ikan diantaranya diversifikasi nugget ikan, bakso ikan, dan kaki naga. Gambar 2 berikut memperlihatkan bentuk diversifikasi ikan.

Program penyediaan dan pemenuhan makanan yang B2SA dan P2KP terutama protein sangat penting, karena protein mempunyai peranan utama sebagai pembangun, pengganti bagian sel yang rusak, sebagai enzim, hormon, antibodi, dan lain-lain., yang tidak dapat digantikan oleh zat gizi yang lain. Ikan merupakan sumber protein hewani yang murah, mudah didapat dan halal. Penganekaragaman jenis olahan ikan di masyarakat belum banyak dijumpai dan belum berkembang, karena menu sehari-hari masih monoton. Menu yang demikian sudah berlangsung cukup lama, sehingga bagi ibu hamil dan anak-anak terutama balita dan batita cepat merasa bosan, padahal mereka perlu mengkonsumsi protein yang lebih tinggi untuk pertumbuhan otak. Untuk mencegah hal tersebut agar tidak terjadi, perlu penyediaan makanan yang B2SA, dengan cara penganekaragaman bentuk olahan ikan berupa kaki naga ikan dan nugget ikan. Jika usaha penganekaragaman bentuk olahan ikan dapat digalakkan, maka program pemerintah tentang P2KP dapat tercapai. Hasil penyuluhan menunjukkan bahwa produk yang ditawarkan berupa kaki naga ikan dan nugget ikan mendapat respon yang baik dan diterima di masyarakat, karena mereka memperhatikan dengan seksama tentang demo pembuatan kaki naga ikan, nugget ikan, dan bakso ikan. Berikut ini dilihatkan demonstrasinya pada Gambar 3.

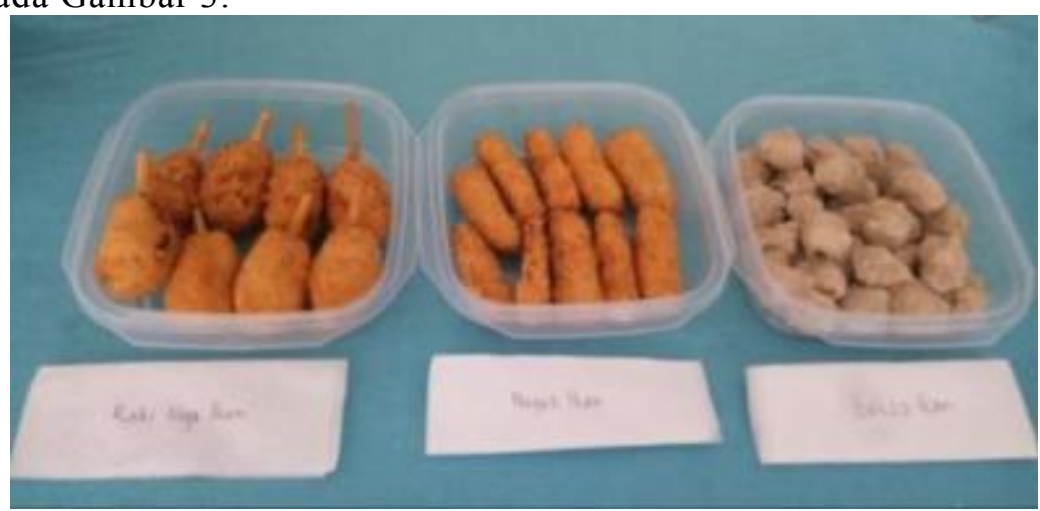

Gambar 2. Bentuk Diversifikasi Kaki Naga Ikan, Nugget Ikan, dan Bakso ikan.

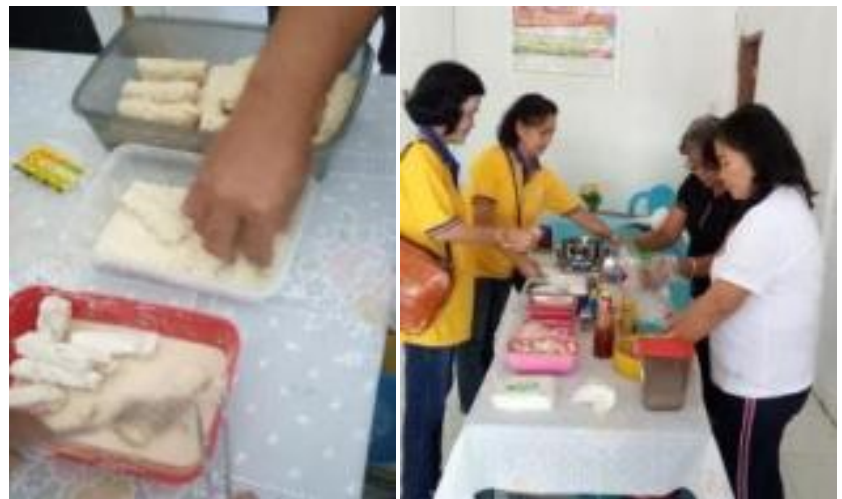

Gambar 3. Demonstrasi Pembuatan Kaki Naga, Nugget Ikan, Bakso ikan.

\section{Produk Diversifikasi}

\section{a. Kaki Naga Ikan}

Produk kaki naga ikan adalah jenis olahan dimana ikan dibuat pasta dan ditambah bumbubumbu lada garam, bawang bombay, akar kuning dan telur, kemudian dibentuk bulat lonjong dan secara spesifik ditusuk dengan stik es krim. Terakhir adalah simpan kaki naga ini pada freezer hingga beku. Setelah produk beku siap digoreng hingga warnanya kekuning-kuningan/keemasan. Disajikan dalam bentuk digoreng dengan minyak panas.

Kaki Naga ikan adalah salah satu produk olahan menggunakan berbagai jenis ikan yang murah dan tersedia banyak agar termanfaatkan dan rasanya menjadi lebih enak. Proses pembuatan 
kaki naga memerlukan perhatian terkait dengan tingkat kesegaran ikan. Konsistensi dan elastisitas daging ikan akan menghasilkan produk kaki naga yang lembut dan mudah dibentuk. Ciri-ciri ikan segar adalah mata cerah, kulit elastik artinya jika ditekan tidak menimbulkan bekas, insang warna merah cerah dan mempunyai bau khas ikan segar. Dalam penanganan daging ikan, memerlukan waktu secepatnya, tepat dan saniter agar selama pengolahan tidak terjadi kemunduran mutu.

Pembuatan produk kaki naga ikan meliputi tahapan sebagai berikut: Pertama, ikan disiangi dalam kondisi segar, lalu dicuci dengan air mengalir kemudian dilakukan pemisahan daging. Proses pemisahan daging ikan dengan kulit, yaitu ikan dibelah dua kemudian dagingnya dikeruk dengan sendok sehingga terpisah dengan kulit. Daging ikan dimasukkan pada wadah yang berisi air kemudian dilumatkan dengan tangan atau alat penghancur daging. Pencucian daging dilakukan berulang-ulang sampai air tidak berwarna merah, lalu ditiriskan. Daging yang siap dibentuk dan digunakan untuk berbagai produk diversifikasi dikenal dengan istilah pasta ikan tersaji pada Gambar 4 .

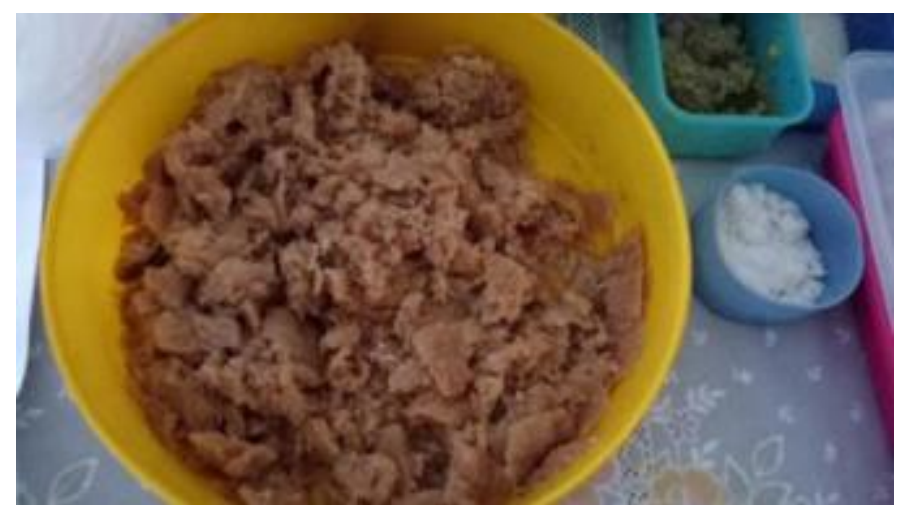

Gambar 4. Pasta ikan siap diolah berbagai produk diversifikasi.

Tahap kedua, yaitu pasta ikan sebanyak $500 \mathrm{~g}$ ditambahkan berbagai bahan dan rempahrempah, sebagai berikut: $100 \mathrm{~g}$ terigu, $50 \mathrm{~g}$ maizena, 1 sendok baking powder, $2 \mathrm{sdm}$ bawang bombay, $2 \mathrm{sdm}$ bawang putih, $1 / 2 \mathrm{sdm}$ gula putih, $1 \mathrm{sdt}$ merica halus, putih telur 2 butir, $3 / 4 \mathrm{sdm}$ garam , $50 \mathrm{~g}$ wortel yang diiris kecil/halus, dan minyak goreng. Telur, bawang putih dan bawang Bombay dicampur dengan pasta ikan dan ditambahkan garam, merica sambil diaduk sampai tercampur merata. Kemudian ditambahkan terigu dan maizena sambil diaduk/dicampur dengan tangan sampai adonan merata dan dapat dibentuk bulat lonjong menggunakan sarung tangan. Tahap ketiga, Adonan dibentuk bulat lonjong kemudian ditusuk dengan stik es krim. Adonan dikukus selama 15 menit, lalu diangkat dan dibiarkan dingin dan simpan dalam lemari pendingin selama1 jam. Sementara itu, menyiapkan tepung pre-dust, yaitu campuran bahan-bahan: $300 \mathrm{~g}$ tepung terigu $+100 \mathrm{~g}$ maizena + bumbu penyedap + bawang putih hancur. Adonan Pre-mix, yaitu campuran $250 \mathrm{~g}$ tepung terigu $+150 \mathrm{~g}$ maizena +2 sdt baking powder +2 btr telur ayam $+450 \mathrm{ml}$ Air Es+Bumbu (garam, gula, merica, bawang putih dan penyedap royco secukupnya,diaduk/dimixer sampai merata), dan bread-crumbs (tepung remah roti). Tahap akhir, yaitu produk dicelupkan ke dalam kocokan putih telur lalu dibalut dengan tepung roti. Selanjutnya dilakukan penggorengan sebentar dalam minyak panas. Proses penggorengan dapat dilakukan pada saat dibutuhkan. Produk kaki naga sebelum dan setelah digoreng dapat dilihat pada gambar 5 .
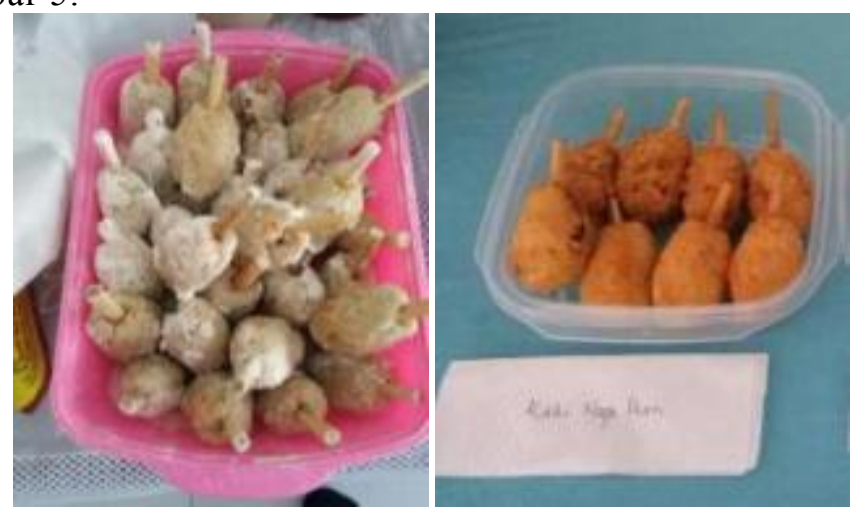

Gambar 5. Produk kaki naga ikan sebelum dan setelah digoreng. 


\section{b. Nuget Ikan}

Nugget Ikan adalah produk diversifikasi lezat, disukai dan praktis sebagai lauk. Disajikan dalam bentuk ikan yang digoreng. Bumbu bawang putih dicincang dan dicampur dengan garam dan merica secukupnya dan diaduk hingga rata. Pasta dimasukkan dalam loyang yang sudah diolesi dengan minyak lalu taruh bahan adonan, dikukus hingga matang sekitar 30 menit, angkat dan dinginkan. Apabila sudah dingin adonan bisa dicetak ataupun dibentuk sesuai selera, setelah itu balut menggunakan putih telur lalu gulingkan pada tepung panis. Hal yang sama dilakukan hingga dua kali pelapisan dan juga lakukan hal yang sama hingga adonan habis. Terakhir adalah simpan nugget ikan ini pada freezer hingga beku. Setelah nugget ikan beku, maka nugget siap digoreng hingga warnanya kekuning-kuningan.

Tahapan pembuatan produk nugget ikan membutuhkan bahan sebagai berikut: bahan baku terdiri dari $500 \mathrm{~g}$ pasta ikan, 50g biji wijen putih atau 50g parutan keju, $1 \mathrm{sdm}$ bawang putih, $1 \mathrm{sdt}$ gula, $1 \mathrm{sdt}$ garam, $1 / 4 \mathrm{sdt}$ jahe tumbuk, $50 \mathrm{~g}$ roti tawar, Minyak goreng. Bahan pelapis nugget yakni Tepung pre-dust, adonan pre-mix dan tepung roti seperti pada kaki naga. Cara pembuatan nugget ikan, adalah (1) daging ikan digiling atau dicincang sampai halus. (2) bawang putih, bawang bombay dan telur diblender. (3) roti direndam dalam cairan susu dan dihancurkan. (4) semua bahan (kecuali tepung roti) dicampur sampai homogen kemudian dimasukkan ke wadah yang sudah dilapisi dengan mentega atau minyak goreng, kemudian dikukus. Setelah masak dipotong sesuai selera, dicelup di telur, dilabur dengan tepung roti kemudian digoreng. Selesai digoreng nugget ikan siap untuk disantap. Gambar 6 berikut memperlihatkan proses pembuatan nugget ikan.

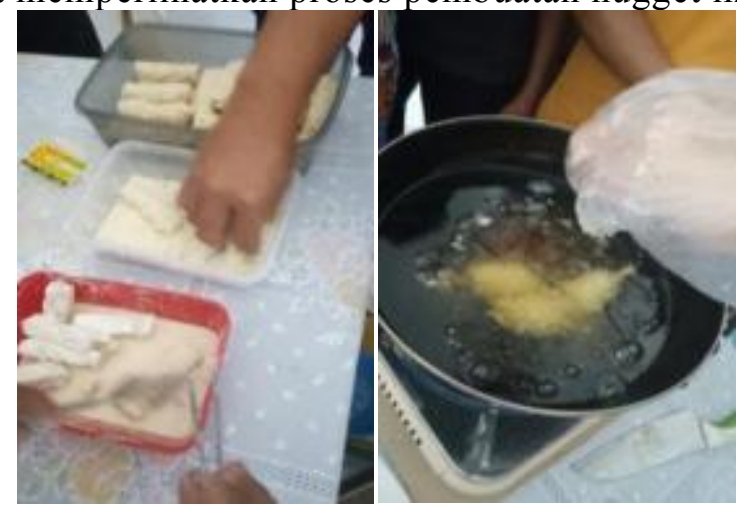

Gambar 6. Proses Pembuatan Nuget Ikan.

\section{c. Bakso Ikan}

Bakso Ikan adalah jenis diversifikasi produk olahan dengan bahan baku daging ikan. Bahan lain dicampurkan dengan daging ikan yang sudah dihaluskan dengan bumbu halus dan beri tambahan gula, merica, dan garam. Terakhir tambahkan putih telur dan tepung tapioka, aduk merata. Adonan tidak terlalu basah dan tidak terlalu kalis, bentuknya masih seperti hasil gilingan ikan (semi basah) dengan bantuan 2 buah sendok, dibentuk dengan telapak tangan bulat-bulat, dan masukkan ke dalam air mendidih. Tunggu bakso mengapung dan matang, lakukan berulang-ulang sampai adonan habis. Siap dipakai untuk tambahan berbagai masakan. Gambar 7 memperlihatkan proses pembuatan bakso ikan.

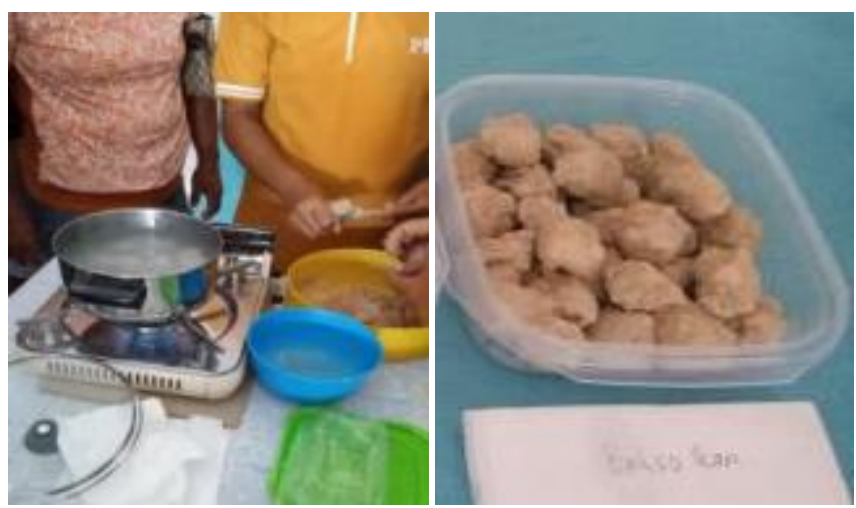

Gambar 7. Proses Pembuatan Bakso ikan 
Pelatihan dan Pendampingan Pelatihan dan pendampingan dilakukan setelah para kelompok ibu-ibu mendengarkan dengan seksama materi penyuluhan yang disampaikan. Pada waktu penyuluhan, para ibu-ibu sangat senang dan antusias untuk mengikuti penyuluhan, sehingga ada banyak pertanyaan dari ibu-ibu tentang materi yang disampaikan, karena mereka menyadari bahwa penganekaragaman bentuk olahan ikan sangat diperlukan, supaya mereka tidak bosan menyajikan menu makanan yang bervariasi. Pada waktu pelatihan dan pendampingan hampir semua ibu-ibu berebut ingin mencoba cara pembuatan kaki naga ikan dan nugget ikan. Rasa dan bentuk kaki naga ikan, nugget ikan, dan bakso ikan mendapat respon yang baik dari kalangan anak-anak, remaja, bapak-bapak dan ibu-ibu. Bukti keseriusan mereka dalam mengikuti pelatihan dan pendampingan dapat dilihat pada gambar 8 .

Pengamatan dan evaluasi terhadap kegiatan mulai tahap penyuluhan, pelatihan dan pendampingan dalam pembuatan kaki naga, nugget ikan, dan bakso ikan menunjukkan bahwa para wanita dan ibu-ibu sangat antusias terutama dalam penyuluhan, mereka sangat aktif mendengar, memperhatikan dan bahkan mengajukan pertanyaan. Saat pelaksanaan pelatihan dan pendampingan para ibu-ibu berebut ingin mencoba melakukan dan mempraktekkan sendiri cara pembuatan kaki naga dan nugget ikan, sehingga pada waktu disajikan dalam salah satu acara, tidak membutuhkan waktu yang lama, kaki naga dan nugget ikan tersebut langsung habis. Ini membuktikan bahwa solusi yang ditawarkan, dalam hal ini pembuatan kaki naga ikan dapat diterima oleh masyarakat. Sangat diharapkan melalui solusi yang ditawarkan ini, berupa pembuatan kaki naga, dan nugget ikan merupakan salah satu cara untuk mewujudkan program pemerintah tentang pelaksanaan B2SA dan P2KP. Evaluasi diukur selain dengan bukti dokumen, juga disebarkan suatu lembaran kuesioner, dimana pada lembaran tersebut diajukan pertanyaan-pertanyaan dan pilihan jawaban, yang dapat diisi oleh peserta dengan memilih jawaban yang tersedia dengan cara memberi tanda cek $(\sqrt{ })$ pada samping jawaban yang tersedia sesuai pilihannya. Data kuesioner yang dibagikan sebanyak 25 lembar, dengan penilaian masing-masing mulai dari cita rasa, aroma, penampakan, warna dan tekstur yang menilai menyukai ke tiga produk ada sebanyak $70 \%$, sangat suka $30 \%$, ibu-ibu yang mau membuat di rumah ada $90 \%$, yang dapat menebak bahwa cara pembuatan ketiga produk $95 \%$ menyatakan mudah, bahan dan bumbu yang diperlukan 95\% menyatakan mudah didapat. Selanjutnya semua peserta $100 \%$ menyatakan bahwa produk kaki naga dapat dijadikan bahan bisnis yang menjanjikan bagi peningkatan ekonomi.

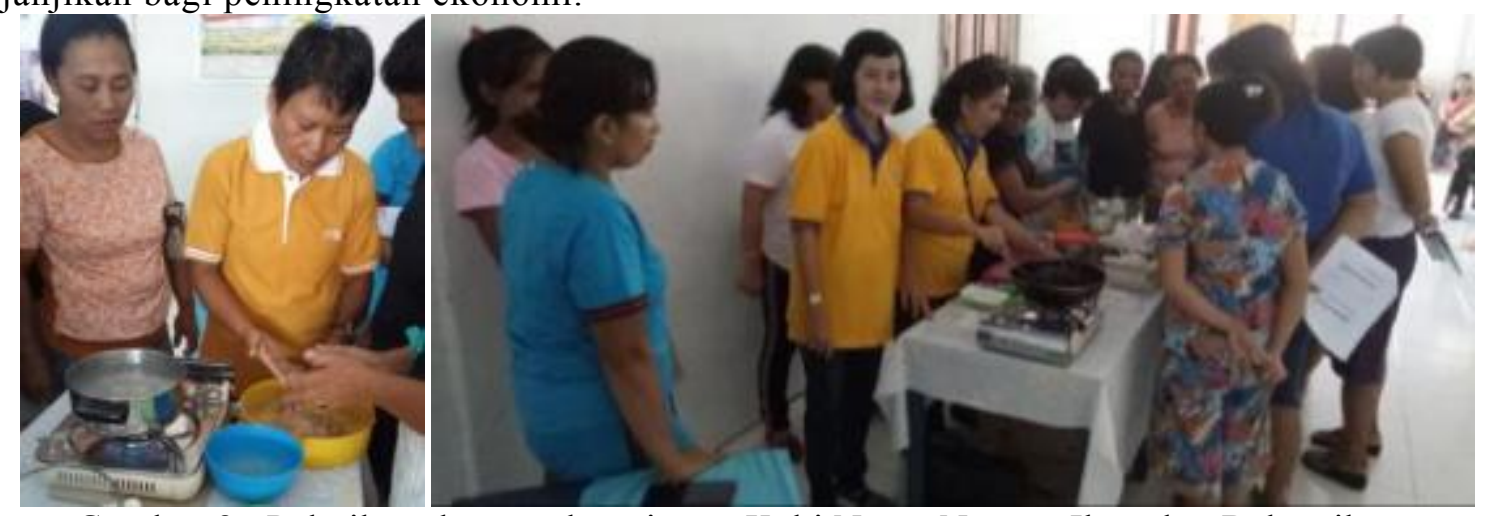

Gambar 8. Pelatihan dan pendampingan Kaki Naga, Nugget Ikan dan Bakso ikan.

\section{KESIMPULAN}

Pelaksanaan Program Kemitraan pada kelompok masyarakat secara khusus ibu-ibu di desa Darunu Kecamatan Wori Kabupaten Minahasa Utara, dapat disimpulkan sebagai berikut:

1. Peserta Program Kemitraan Masyarakat adalah wanita dan ibu-ibu yang memiliki minat mengikuti perubahan dan kemauan untuk meningkatkan pengetahuan berkaitan dengan jenis menu yang disajikan setiap hari.

2. Produk diversifikasi kaki naga, nugget ikan, dan bakso ikan dapat menyediakan menu ikan dengan rasa enak, meskipun terbuat dari jenis ikan yang kurang disukai sebagian besar masyarakat. Hanya $5 \%$ panelis yang dapat menentukan ikan sebagai bahan baku kaki naga dan nugget ikan. Hal ini menunjukkan bahwa kaki naga dan nugget ikan dapat menciptakan rasa yang baru dan enak, 
sehingga hasil menunjukkan bahwa $100 \%$ panelis ingin membuat produk olahan tersebut di rumah masing-masing.

3. Produk kaki naga, nugget ikan dan bakso ikan berpeluang untuk dijadikan bisnis baru bagi para ibu yang menopang pendapatan keluarga/masyarakat, dimana mayoritas peserta pelatihan berkeinginan meneruskan kegiatan usaha tersebut.

\section{DAFTAR PUSTAKA}

Damongilala, L.J.dan Montolalu,L.A.D. 2017. Gizi Pangan Ikani. Penerbit Indi.

Djuhria,W.dan A. Reo. 2018. Diversifikasi Produk Olahan Ikan di Kelurahan Tongkaina Kecamatan Bunaken Kota Manado. Jurnal Media THP no. Vol..

Harikedua J. 2019. Hand-out. Bahan Pelatihan Pengolahan Kaki Naga \& Nuget berbahan dasar Daging Ikan.

Yuyun Alamsyah.2011 Membuat Sendiri Frozen Food.Seafood Nuget. PT Gramedia Pustaka Utama, Jl Palmerah Barat 33-37, Lt.3 Jakarta 10270.

Santoso, Widya Rusyanto, Sampe Maruli, Devi Hertuti, Dian Agastya, Ati Wahyu, Budi Hartono dan Nilawati. 2011. Peningkatan Nilai Tambah Ikan dan Olahannya Melalui Teknologi Penanganan dan Pengolahan.Direktorat Pengolahan Hasil DitJen Pengolahan dan Pemasaran Hasil Perikanan Kementrian Kelautan dan Perikanan.Jakarta.128 Halaman. 